\title{
Holocene Vegetation and Land Use History in the Northern Vosges [France]
}

\author{
Dirk Sudhaus, Arne Friedmann
}

\begin{abstract}
How to cite:
Sudhaus, D. \& Friedmann, A. (2015): Holocene Vegetation and Land Use History in the Northern Vosges (France). - E\&G Quaternary Science Journal, 64 (2): 55-66. DOI: 10.3285/eg.64.2.01
Abstract: $\quad$ A radiocarbon-dated peat profile from Rond Pertuis supérieure mire in the uplands of the Northern Vosges is studied using palynological methods. The profile dates from the middle Atlantic period (4500-3100 B.C.) to recent times.
During the middle of the Atlantic period an oak forest rich in pine covered the Northern Vosges. Fir and beech immigrated at the end of the Atlantic leading to the decline of oak and pine in the forest. This also marked the onset of decisive human influence on the development of the terrestrial vegetation.
Five land use phases were detected, the first one at the end of the Neolithic period ( $\sim 4000-2200$ B.C.). Subsequently, continuous land use is evident from the Bronze Age (2200-800 B.C.) up to now. In the late Middle Ages (A.D. 900-1500) and the early Mod- ern Era (since A.D. 1500), the woodlands were completely altered by human activities. During the $19^{\text {th }}$ century modern forestry introduced spruce into the investigated area in the Northern Vosges. Spruce afforestation then accelerated in the middle of the $20^{\text {th }}$ century.

Holozäne Vegetation und Landnutzungsgeschichte in den Nordvogesen [Frankreich]

Kurzfassung:

Für das in den Nordvogesen liegende Moor Rond Pertuis supérieure wurde ein mit der ${ }^{14} \mathrm{C}-$ Methode datiertes Pollenprofil erstellt. Das Profil umfasst einen Zeitraum vom mittleren Atlantikum (4500-3100 Jahre v. Chr.) bis heute.

Während der Mitte des Atlantikums bedeckte ein kiefernreicher Eichenmischwald die Nordvogesen. Tanne und Buche wanderten am Ende des Atlantikums ein und führten zu einem Rückgang des Eichen- und Kiefernwaldes. Zu dieser Zeit begann auch der maßgebliche menschliche Einfluss in die Vegetationsentwicklung.

Fünf Landnutzungsphasen konnten differenziert werden, die Erste am Ende des Neolithikums ( $4000-2200 \mathrm{v}$. Chr.). Von der Bonzezeit an (2200-800 v. Chr.) bis in heutige Zeit ist eine kontinuierliche Landnutzung nachweisbar.

Im Spätmittelalter (900-1500 n. Chr.) und der Neuzeit (1500 n. Chr. bis heute) haben sich die Wälder durch die Nutzung vollständig verändert. Im 19. Jahrhundert ist die Fichte in das Untersuchungsgebiet in den Nordvogesen eingeführt worden. In der Mitte des 20. Jahrhunderts wurde die Fichtenaufforstung forciert.

Keywords: $\quad$ Pollen analysis, Holocene, Human Impact, Northern Vosges, France

Addresses of authors: D. Sudhaus, A. Friedmann*, Institut für Geographie, Universität Augsburg, Universitätsstr. 10, D-86135 Augsburg, Germany, E-Mail: friedmann@geo.uni-augsburg.de; *corresponding author

\section{Introduction}

The vegetation history of the Northern Vosges is known through some older pollen studies, which lack chronostratigraphic control. Radiocarbon-dated studies have been limited to the Southern High Vosges (e.g. JANSSEN et al. 1972, 1975, de Valk 1981, Edelman 1985, Kalis 1985, Kalis et al. 2006).

The following studies are available from the Northern Vosges: The Col de Prayé site was examined by Hatт in 1937 and covers the periods from the Boreal to the Sub-Atlantic, but the sample and taxonomic resolution is low, incorporating only six samples over $175 \mathrm{~cm}$, and with only six tree species identified. HATt (1937) also analysed the Soutte bog, the Champ du Feu and the Maxe bog. The Champ du Feu bog was also analysed by BunNIK (1978) as well as the Col de Prayé. The investigations of Firbas et al. (1948) at the Maxe bog cover the period from the Pre-Boreal to the SubAtlantic; GevelaAR's (1982) investigation covers only the Late Glacial period, as does the study of WALTER-SIMONNET et al. (2008), who also studied the tephra in this bog. Firbas et al. (1948) published two undated pollen diagrams from the Northern Vosges: Hochfeld (Champ du Feu) and Schneeberg. The first results of the Rond Pertuis supérieure analysis presented in this study were published by SuDHAUs (2005).

The main features of the Holocene vegetation history are available from these older investigations, particularly the Maxe bog analysis. The younger part of the Holocene period, however, is not represented in this record, because of a hiatus in the profile. Hence, land use history is difficult to reconstruct in detail due to sparse data without independent chronologies. 

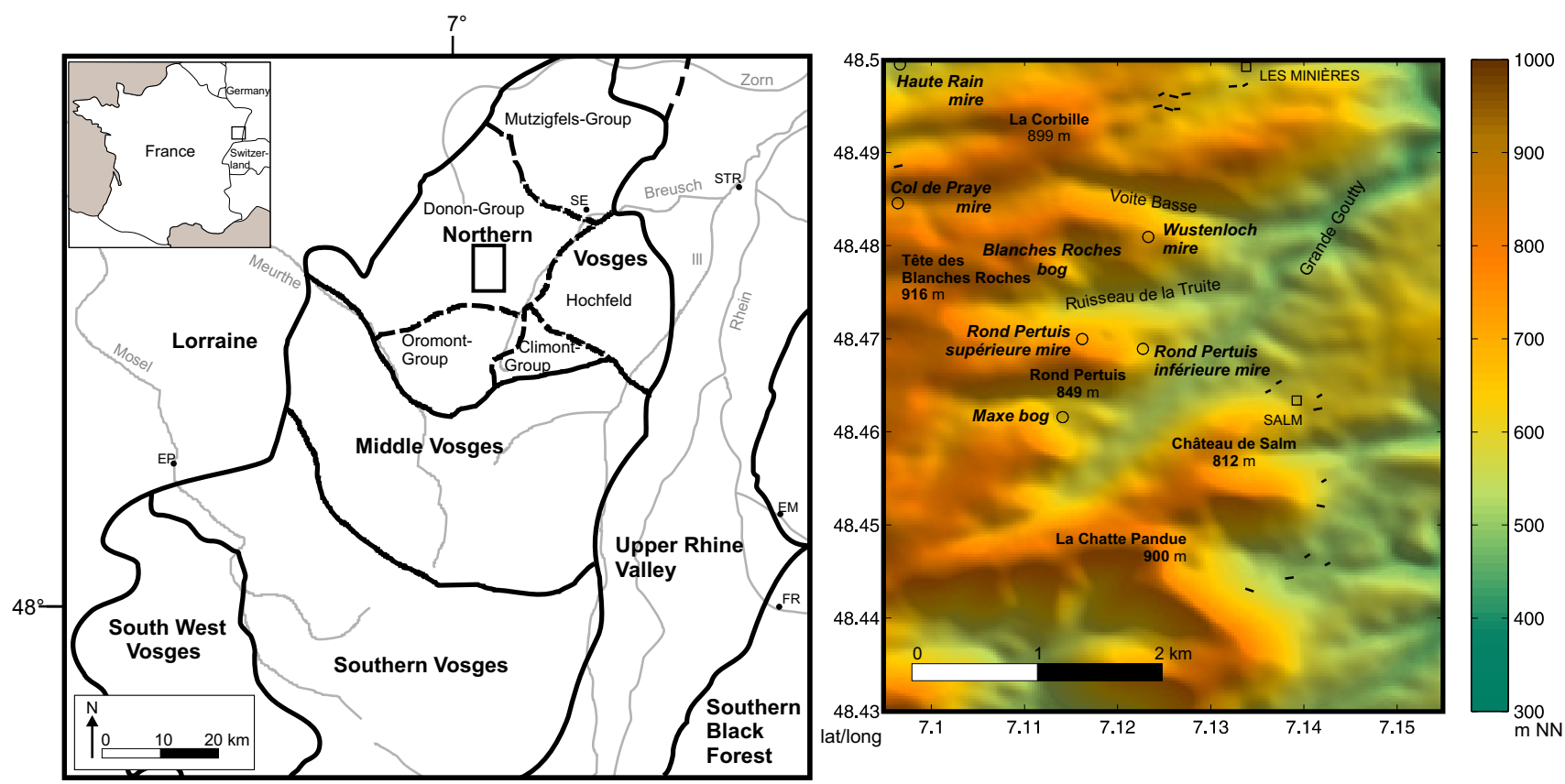

Fig.1: Natural units of the investigation area and locations of the investigated bog (modified after FREY 1965, BREUNING 1998 and SELL et al. 1998, altidues: JARVIS et al. 2008), STR = Strasbourg, SE = Schirmeck, EP = Epinal, Em = Emmendingen, FR = Freiburg.

Abb. 1: Naturräumliche Einheiten des Untersuchungsgebiets und Standorte der untersuchten Moore (nach FREY 1965, BREUNING 1998 und SELL et al. 1998, Höhendaten: JARVIS et al. 2008), STR = Straßburg, SE = Schirmeck, EP = Epinal, Em = Emmendingen, FR = Freiburg.

In order to better understand the natural vegetation development and the impact of anthropogenic activity, more detailed regional palaeoenvironmental records with sufficient dating precision are needed. Here we aim to reconstruct the vegetation history based on a palynological analysis of the bog Rond Pertuis supérieure (Donon Mountain Range), southwest of Strasbourg near Schirmeck (Fig. 1), with an emphasis on reconstructing past human impact on the environment. Little is known about ancient settlements in this upland. Palaeoecological studies can provide insight into the settlement history in this area, identifying and timing agricultural activities and land cover changes. Furthermore a comparison of the later Holocene vegetation development in the Northern Vosges with the Southern Vosges and the Black Forest is given.

\section{Study area}

Mount Rond Pertuis is located at the head of the river Breusch catchment, which is situated within the DononGroup (Northern Vosges, Fig. 1). The bedrock is formed by lower-Triassic reddish sandstones (Buntsandstein) and the common soils in that area are Cambisols and Podzols. The annual precipitation equals $1600 \mathrm{~mm}$ and the mean annual temperature is around $7^{\circ} \mathrm{C}$ (REKLIP 1995). The actual vegetation is dominated by spruce stands that replace the natural beech-fir forests. In the Breusch Valley the forest is dominated by Quercus petraea (sessile oak) (TIMBAL 1985).

Generally the Northern Vosges have a low mire density, but in the study area several small bogs are located (Fig. 1). The best known is the Marais de la Maxe (Maxe bog), first palynologically examined by FirBAs et al. (1948). The majority of bogs are shallow and developed in glacial cirques. Besides the Maxe bog the deepest bog is the Rond Pertuis supérieure with a depth of more than $3 \mathrm{~m}$. All bogs are par- tially drained and/or afforested with Picea abies (Norway spruce).

The bog developed in a northward-oriented glacial cirque. The actual surface vegetation of the Rond Pertuis supérieure bog (690 m a.s.l., 48.46487 N, 7.12626 E) consists of Sphagnum spp. (peat moss), Eriophorum spp. (cotton grass) and other Cyperaceae (sedges). Some parts of the bog are dominated by Drosera rotundifolia (common sundew), and Picea abies and Betula pubescens (white birch) are advancing in the southern part of the bog. In the 1970s the bog was dominated by Sphagnum/Polytrichum (haircap moss). The Sphagnum spp. mosses are in decline on all of the described bogs (Sell et al. 1998). This decline is probably caused by reduced water supply and enhanced shading as a consequence of the expansion of trees on the bog surfaces. Currently the bog is surrounded by a Picea abiesdominated forest.

A Neolithic settlement has been identified by archeologists at the Donon hilltop, about $5 \mathrm{~km}$ to the north of the investigation area. There were also findings from the Iron Age and Roman period, when the site was used as a place of worship (CZARNOwsKy 1947, LINCKENHELD 1947). This shows that the mountain area was visited or settled during these times, but evidence, however, is scarce.

Several tumuli in the Breusch Valley were built during the Metal Ages (LASSERE 2007). A permanent settlement was supported by monasteries in the Breusch Valley from the $6^{\text {th }}$ century onwards, and further settlers arrived in the $10^{\text {th }}$ century. From the $13^{\text {th }}$ to the $19^{\text {th }}$ centuries iron mining was an important regional factor in the upper Breusch Valley nearby, but because of long-lasting wars in Alsace, mining was interrupted in the $17^{\text {th }}$ century (MÜLLER 1905). Mining was most intensive in the $16^{\text {th }}$ century (GARNIER $2000)$. In the $18^{\text {th }}$ century textile industries were the driving force for settlement in the Vosges. 


\section{Material and methods}

From the Rond Pertuis supérieure bog a $300 \mathrm{~cm}$ peat profile was taken with a Russian peat corer at the deepest part of the bog. The profile is situated towards the wall of the cirque. The lowest $60 \mathrm{cms}$ at the bottom showed bad pollen preservation and were not analysed further. The description of the lithostratigraphy follows SPONAGEL (2005).

Pollen analysis was performed with a sub-sampling interval of $4 \mathrm{~cm}$. The samples were processed using standard techniques (adjusted according to FÆGRI and IvERSEN 1989), with $\mathrm{HCl}, \mathrm{KOH}$, acetolysis, $\mathrm{HF}$ and ultrasonic sieving. Pollen grains were identified with the aid of keys (e.g. FÆGRI \& IVERSEN 1989, Moore et al. 1991, Beug 2004), photographs (REILLE 1992), a modern reference pollen collection from Central Europe, and using a microscope with 400-1000 times magnification and phase contrast. Pollen percentages in the diagrams are calculated on a total pollen sum of terrestrial pollen excluding all local types from bog, aquatic and wetland species, Betula, and all ecologically indifferent pollen types like Cyperaceae and Calluna vulgaris (heather). Regional pollen assemblage zones (RPAZ) were defined with the aid of CONISS (GRImm 1987) and based on the terrestrial pollen percentages, excluding the pollen types mentioned above. The additionally shown land use phases (LUP) are based on visual inspection.

Pollen and charcoal concentrations were determined by adding a known amount of Lycopodium spores (STOCKMARR 1971). Only charcoal pieces larger than $38 \mu \mathrm{m}$ have been counted, because these can be correlated with local fires (CLARK et al. 1989). A time control for the sequence was established using six radiocarbon age determinations on bulk samples. The radiocarbon ages were calibrated against the IntCal09 northern hemisphere calibration curve (REIMER et al. 2009) with the OxCal online system (http://c14.arch. ox.ac.uk/) (Table 1). Pollen accumulation rates were calculated with psimpol 4.27 (BENNETT 2009), using a linear interpolation between the available ${ }^{14} \mathrm{C}$-dates.

\section{Results \\ 4.1 Lithostratigraphy and pollen accumulation rates}

The Rond Pertuis supérieure peat profile is underlain by sand (Fig. 2). The lowest layer of the peaty sapropel indicates a limnic origin of the bog. Therefore the Rond Pertuis supérieure is a terrestrialisation bog. Peat growth started with swamp peat in the Atlantic period, as indicated by the deepest radiocarbon date of $245 \mathrm{~cm}$ depth (6205-5925 B.C., Table 1).

From the Sub-Boreal period (3100-800 B.C.) onwards, at $210-10 \mathrm{~cm}$ coring depth, sedge peat and dwarf-shrub peat alternate. During most of the Sub-Atlantic period (800 B.C.-today) dwarf-shrub peat was formed. The uppermost section of the bog is made up of a thin layer of Sphagnum peat, indicating recent acidification and the transition to ombrotrophic bog conditions.

The linear model between the ${ }^{14} \mathrm{C}$ ages, as shown in Fig. 2, suggests a very high peat growth during the Sub-Bo-

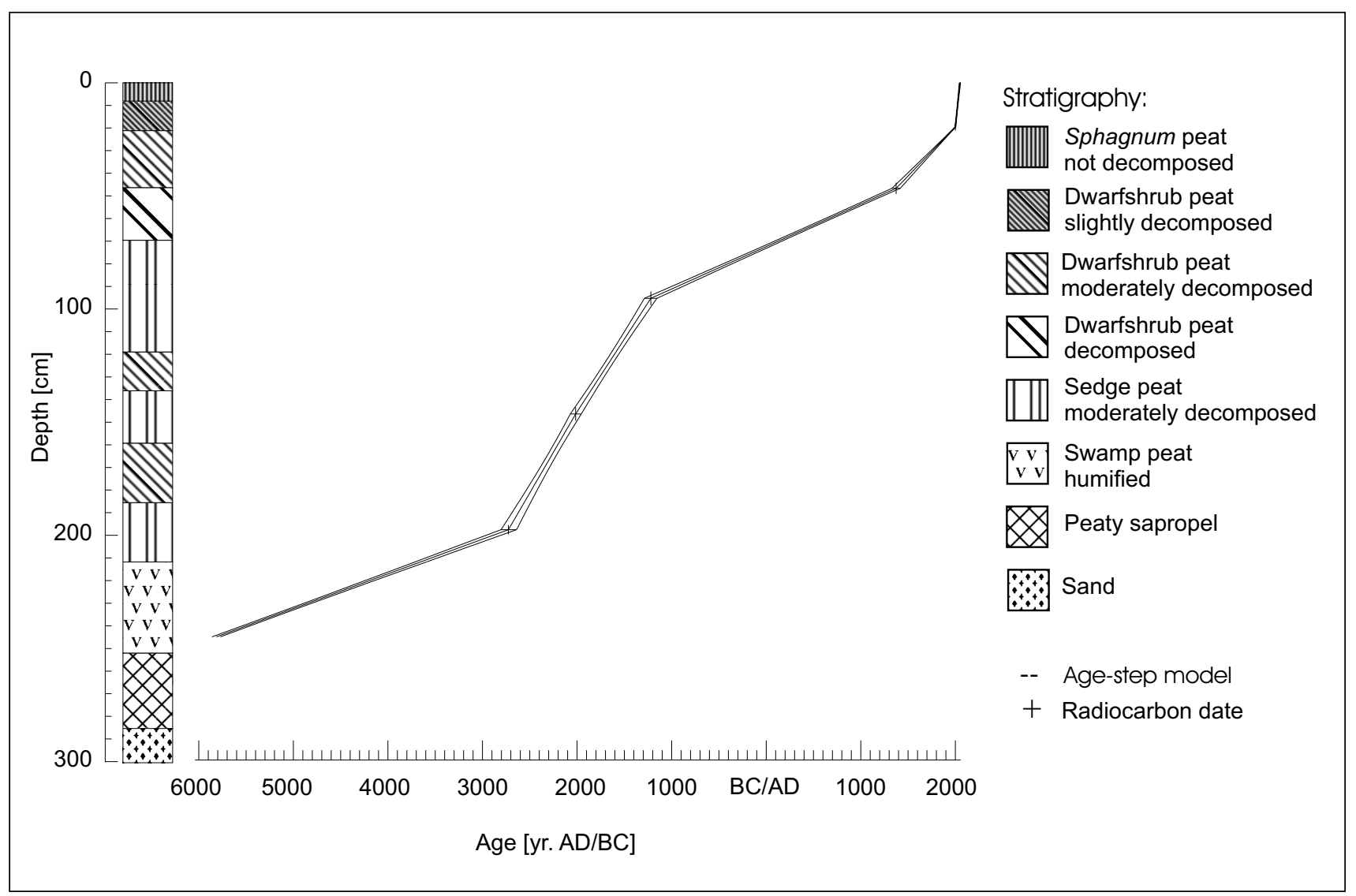

Fig. 2: Stratigraphy and age depth model for the Rond Pertuis supérieure profile. Stratigraphy legend also applies to the presented pollen diagrams (Fig. 3). Abb. 2: Stratigrafie und Alter-Tiefe-Modell für das Bohrprofil aus dem Rond Pertuis supérieure. Gleichzeitig Legende der Stratigrafie im Pollen-Diagramm (Abb. 3). 
Tab. 1: Radiocarbon dates for Rond Pertuis supérieure. ${ }^{14} \mathrm{C}$-analysis was completed by the Heidelberger Akademie der Wissenschaften (Hd), calibration is following REIMER et al. (2009).

Tab. 1: Radiokohlenstoff-Datierungen für das Rond Pertuis supérieure. Die ${ }^{14} \mathrm{C}$-Analyse wurde an der Heidelberger Akademie der Wissenschaften (Hd) durchgeführt, die Kalibirierung der Daten erfolgte nach REIMER et al. (2009).

\begin{tabular}{|c|c|c|c|c|}
\hline Depth [cm surface] & Laboratory sample No. & ${ }^{14}$ C-date BP & 2 $\boldsymbol{\sigma}$ date AD/BC & Sample substratum \\
\hline $18-21$ & Hd-23583 & modern & modern & dwarfshrub peat \\
\hline $44-49$ & Hd-23581 & $677 \pm 53$ & AD 1255-1405 & dwarfshrub peat \\
\hline $92-98$ & Hd-23564 & $3016 \pm 35$ & $1390-1130$ BC & sedge peat \\
\hline $143-149$ & Hd-23565 & $3679 \pm 36$ & $2195-1950$ BC & sedge peat \\
\hline $195-199$ & Hd-23582 & $4197 \pm 58$ & $2910-2620$ BC & swamp peat \\
\hline $245-249$ & Hd-23586 & $7173 \pm 45$ & $6205-5925$ BC & \\
\hline
\end{tabular}

real period (SudHaus 2005). This results in relatively high pollen accumulation rates during this time (Fig. 4). Lower pollen accumulation rates for the Sub-Atlantic period are given by a general line-fitting, but with regard to the whole diagram, the linear model used results in the most plausible pollen accumulation rates. Overall, the pollen accumulation rates do not vary greatly.

\subsection{Pollen stratigraphy}

The pollen stratigraphy within the profile of Rond Pertuis supérieure stretches from the middle of the Atlantic period to the present time (Fig. 3a and b). Four regional pollen assemblage zones (RPAZ, Table 2) were distinguished.

RPAZ 1 (240-218cm): Quercetum mixtum - Corylus - Pi$n u s$, middle Atlantic period.

A mixed oak forest also rich in Pinus (pine) and Corylus (hazel) covered the area during RPAZ 1. Abies (fir) and Fagus (beech) pollen appear simultaneously at the end of RPAZ 1.

RPAZ 2 (218-134cm): Abies - Fagus, late Atlantic to middle Sub-Boreal period.

The pollen values of Quercus, Pinus and Corylus decrease after the appearance of Fagus and Abies. This decrease is also visible in the pollen accumulation rates diagram and is accompanied by a decrease of the total influx sum (Fig. 4). The pollen abundance of Fagus rises slowly and more continuously compared to Abies, and accumulates slowly and constantly. Abies values decline immediately after the initial rise, and this is also reflected in the accumulation rates, and in the varying abundance, including two further maxima around $45 \%$. The increase of the Fagus values continues until the middle of the Sub-Boreal period, where $\mathrm{Fa}$ gus becomes the dominant pollen type. At the beginning of RPAZ 2 the abundance of Poaceae (grasses) and some herbs increases. In the middle of RPAZ 2 the first Cerealia (cereals) pollen type, Hordeum type (inter alia barley), was found, accompanied with rising values for non-arboreal pollen (NAP).

At the end of RPAZ 2 the Abies percentages show a sharp decline, while the Fagus, Corylus and Pinus abundances increase.

RPAZ 3 (134-42cm): Fagus - Abies - Pinus, middle SubBoreal to middle Sub-Atlantic period.

The Pinus values remain elevated, while Abies remains at a level around 20\%. Plantago lanceolata (ribwort plantain) is almost continuously evident during this RPAZ. Carpinus (hornbeam) pollen was detected from the middle of RPAZ 3 onwards. From then on Artemisia (mugwort etc.) pollen were found almost continuously and the Plantago lanceolata curve increases. At the end of RPAZ 3 Pinus abundance decreases to a very low level, while the Corylus pollen influx increases (Fig. 4).

RPAZ 4 (42-0cm): (Picea -) Pinus - NAP (non-arboreal pollen), late Sub-Atlantic period.

At the beginning of RPAZ 4 Quercus values are higher than before. Pinus pollen at first has a low representation but then rises right up until recent times. In the middle of RPAZ 4, when Quercus levels fall, Abies increases first but decreases afterwards, while the pollen percentages of Fagus remain at a low level. Betula and Corylus frequencies rise. In the second part of RPAZ 4 Picea shows increasing values.

Tab. 2: Regional pollen assemblage zones at the Rond Pertuis supérieure. NAP = non-arboreal pollen, QM =Quercetum mixtum.

Tab. 2: Regionale Pollenzonen am Rond Pertuis supérieure. $N A P=$ Nichbaumpollen, $Q M=$ Eichenmischwald.

\begin{tabular}{|c|c|c|c|c|}
\hline \multirow{2}{*}{ PAZ } & \multirow{2}{*}{ Dominant pollen types } & \multirow{2}{*}{ Depth in cm } & \multicolumn{2}{|c|}{ Boundary } \\
\hline & & & Rise & Decline \\
\hline 4 & [Picea -] Pinus - NAP & $42-0$ & \multirow{4}{*}{$\begin{array}{l}\text { Corylus, NAP and Quercus } \\
\text { Pinus } \\
\text { Abies and Fagus }\end{array}$} & \multirow{4}{*}{ Pinus and Abies } \\
\hline 3 & Fagus - Abies - Pinus & $134-42$ & & \\
\hline 2 & Abies - Fagus & $218-144$ & & \\
\hline 1 & Quercetum mixtum - Corylus - Pinus & $240-218$ & & \\
\hline
\end{tabular}




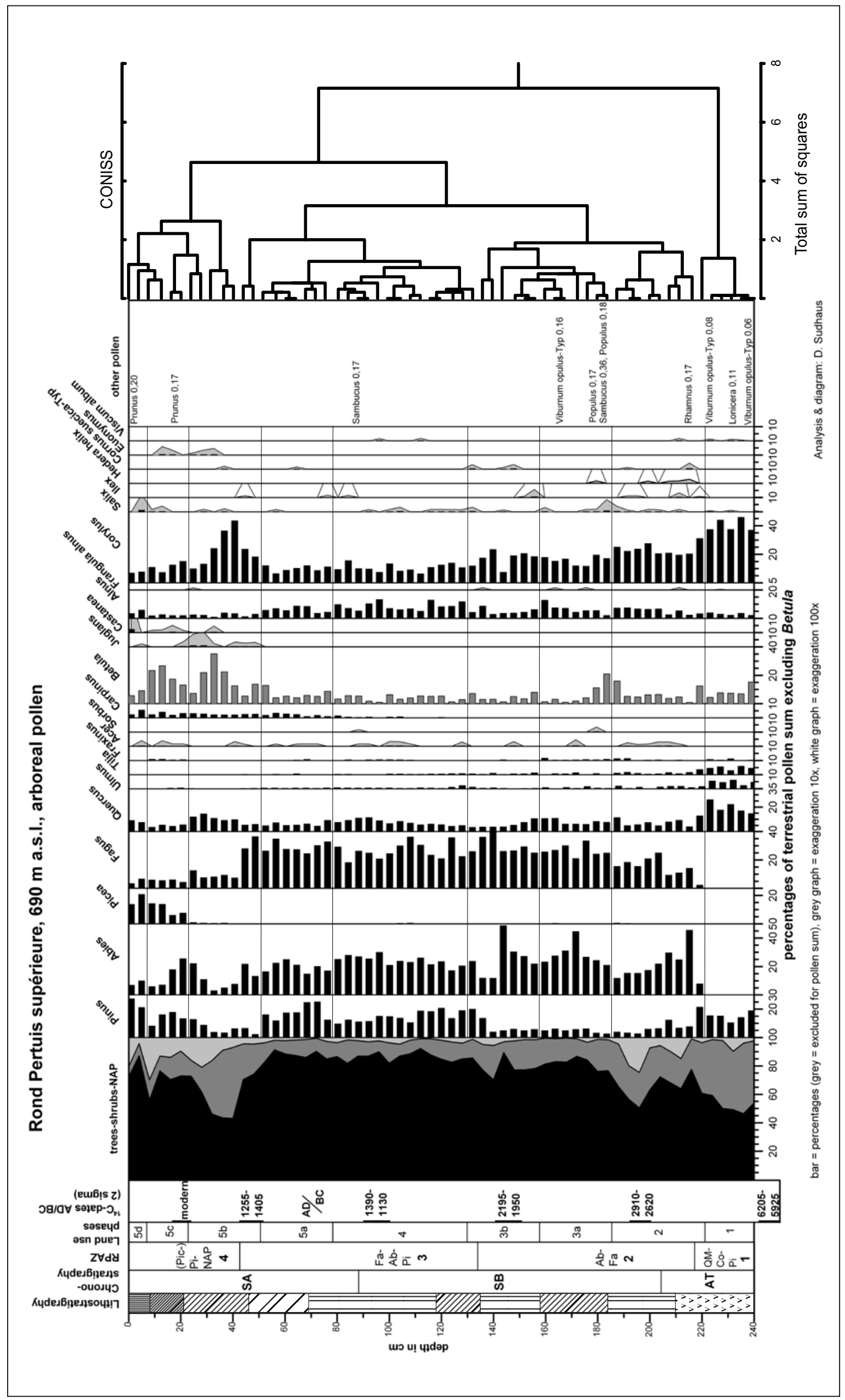




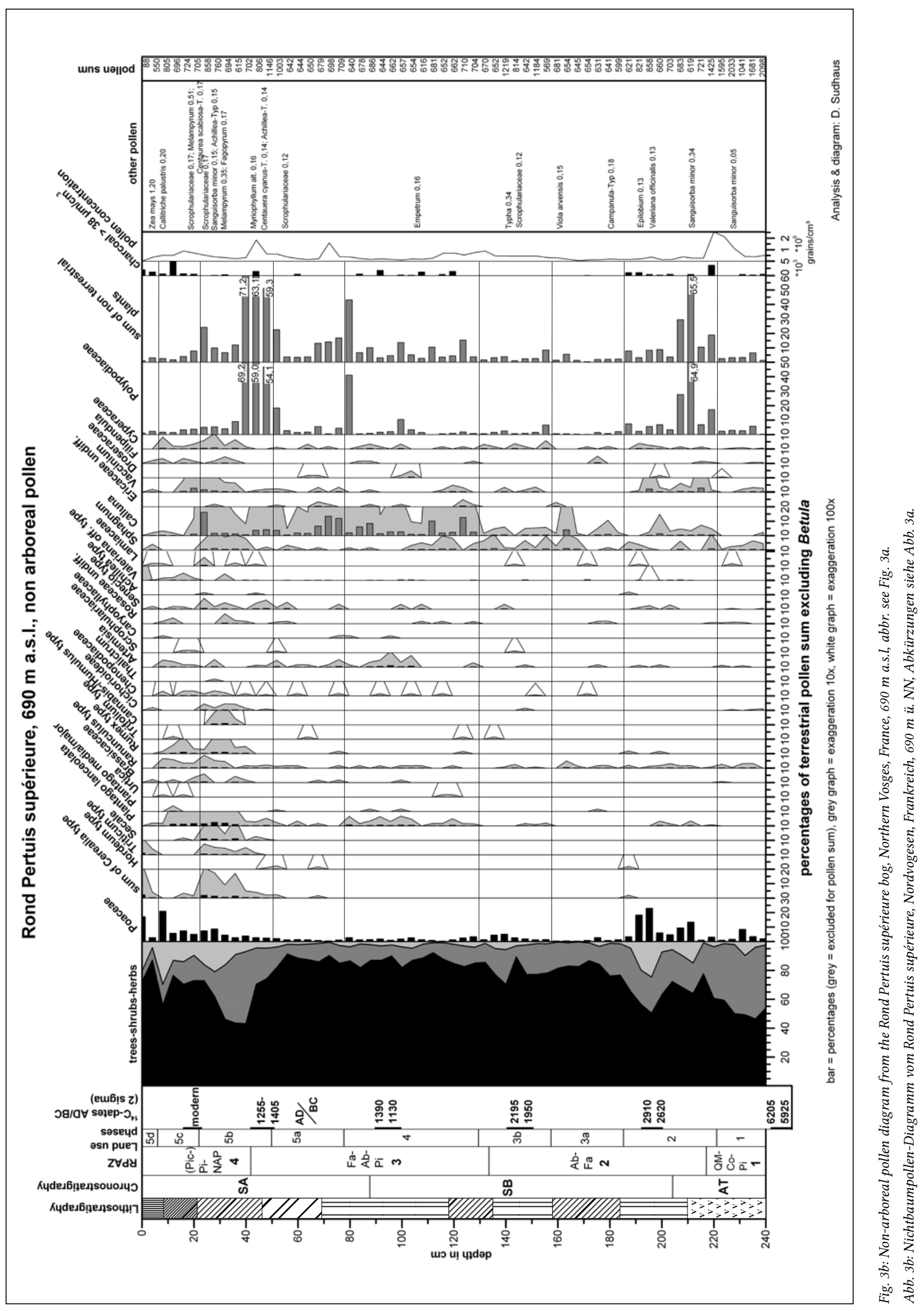




\section{Rond Pertuis supérieure, $690 \mathrm{~m}$ a.s.I., pollen accumulation rates, selected Taxa}
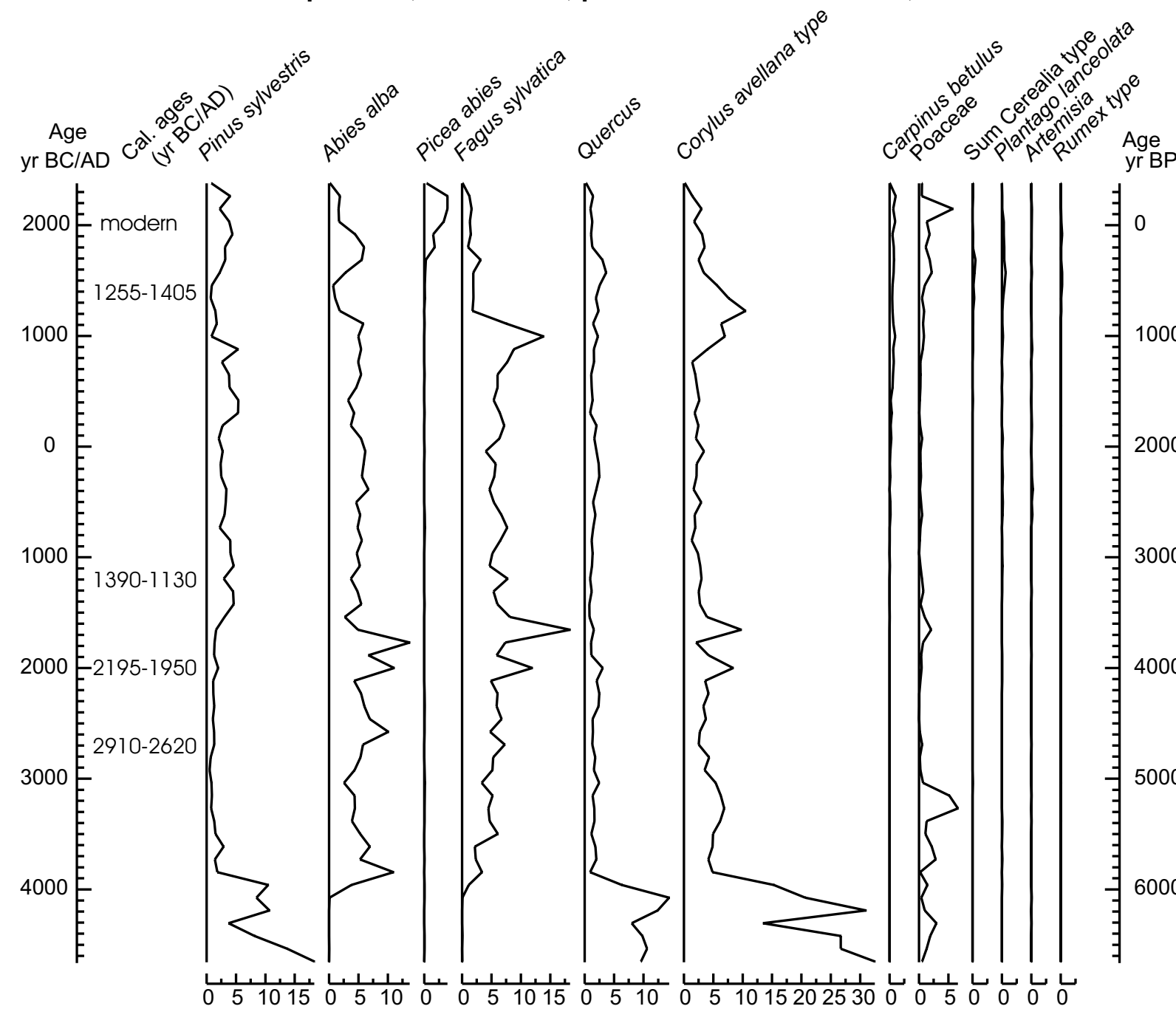

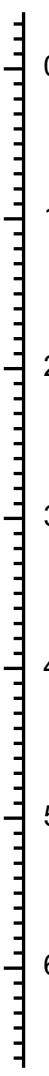

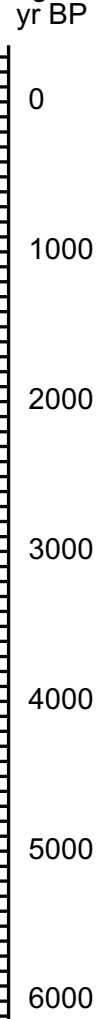

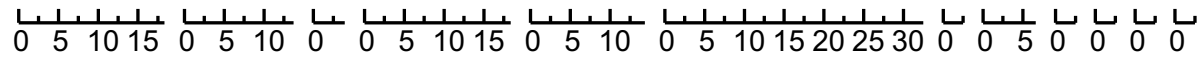

grains $\mathrm{cm}^{-2}$ year 1

Fig. 4: Pollen accumulation rates from the Rond Pertuis supérieure bog, Northern Vosges, France, 690 m a.s.l with selected Taxa.

Abb. 4: Raten des Pollenniederschlags für ausgewählte Taxa des Rond Pertuis supérieure, Nordvogesen, Frankreich, $690 \mathrm{~m}$ ü. NN.

\section{Discussion}

\subsection{Pollen source area}

Following Sugita (1994), the pollen source area for a lake with the dimensions of the Rond Pertuis supérieure bog is less than $800 \mathrm{~m}$ from the lake-shore. The pollen assemblage from a bog differs from a lake of similar radius (SUGITA 1993). According to Huntley and WebB (1988), in a site of this size most of the pollen arises from a $500 \mathrm{~m}$ radius. We suppose that the pollen source area in this mountain area with a distinctive relief, may be even larger. Maximum pollen emission for a lot of plants takes place at noon (ZwANDER 1997). During this time the quasi-periodic valley wind regime may transport pollen from lower altitudes to the higher ones. Most of the deposited pollen must be transported by air, only during the lake period of the Rond Pertuis supérieure transportation by water from the small catchment area in the south / southwest is possible.

According to this interpretation we examined the radius of $1 \mathrm{~km}$ around the bog more closely, which most likely represents the possible pollen source area. Fig. 5 is showing aspect, elevation and slope for a radius of $1 \mathrm{~km}$ around the coring point in the Rond Pertuis supérieure bog based on the $90 \mathrm{~m}$ digital SRTM elevation model (JARVIS et al. 2008). As shown in Fig. 1 the Rond Pertuis supérieure is situated at the Ruisseau de la Truide valley, which is east-west orientated. Most of this valley is in a $1 \mathrm{~km}$ circle around the bog, which implies that the expected pollen source of the area has an eastern aspect. High southern aspect rates are found on the north side of the valley. The elevation of the assumed pollen source area ranges from 440 to $810 \mathrm{~m}$ a.s.l. Most parts of the area have slopes between 10 and 25 degrees. Agriculture may be possible only up to a slope of 15 degrees. So about $40 \%$ of the estimated pollen source area may be suitable for agriculture, but this is an overestimation, because most of the levelled area is found on the bog itself. Additional steep slopes are under-represented in the figure, because the resolution of the SRTM data causes an inadequate representation of the steep slope of the cirque. 


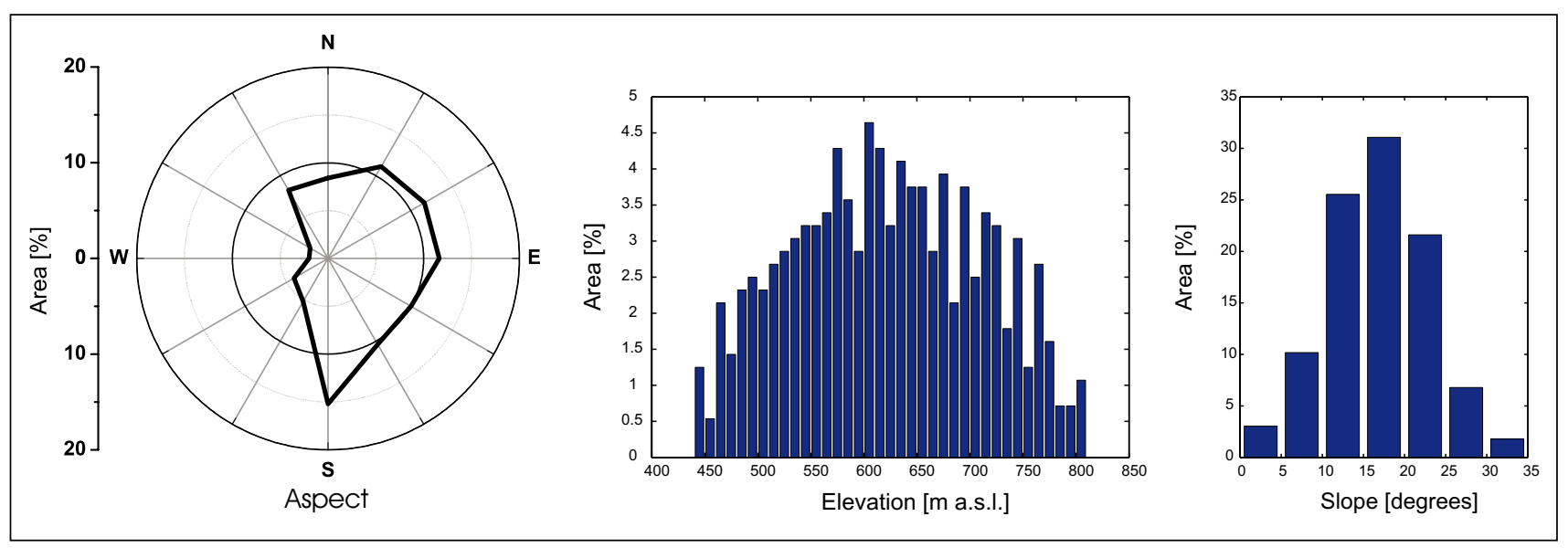

Fig. 5: Aspect, elevation and slope in a $1 \mathrm{~km}$ radius around the coring point in the Rond Pertuis supérieure bog.

Abb. 5: Verteilung von Exposition, Höhe und Neigung im Umkreis von $1 \mathrm{~km}$ um den Bohrpunkt im Rond Pertuis supérieure.

\subsection{Natural Vegetation}

The pre-Atlantic vegetation history, despite being absent in the presented pollen diagrams, can be reconstructed from the Maxe bog analysis (Firbas et al. 1948). In the Pre-Boreal and Boreal periods Pinus, Corylus and Betula were the dominant species. The decline of Corylus pollen in the Maxe bog indicates the expansion of a mixed oak forest from the Boreal to the late Atlantic period.

From the middle Atlantic period (approx. 5000 B.C.) onwards the vegetation history is represented in the Rond Pertuis supérieure diagram (Figs. 3a and 3b).

The high representation of Pinus and Corylus pollen in the oak forest during the Atlantic period indicates an occurrence of these species. Either the oak-dominated forests were open enough for these heliophilous tree species, or perhaps Pinus and Corylus grew in different areas to the mixed oak forest species, e.g. on the steep slopes of the cirque. The low number on heliophilous herbs does not indicate an open oak forest. Pinus might have grown on the well drained sites, whereas Colyus needs moister conditions (Theuerkauf et al. 2014) and therefore could have grown around the lake.

As the profile of the Maxe bog is showing high values of Pinus and Corylus and a very slow decline of both species from the Boreal period onwards, this may represent a natural phenomenon in the northern sandstone Vosges (FIrBAS et al. 1948, Friedmann 2000), and not a local effect at the Rond Pértuis site. In the Maxe profile Pinus is also detected in macrofossils, so a local occurrence is likely (FIRBAs et al. 1948). The long persistence of Pinus could hence be attributed to the more acidic soils on the sandstone bedrock. The harsher environmental conditions of the cirques (shadier, cooler and moister) may give ecological advantage to the establishment of pine-dominated ecosystems, thus hampering the immigration of other tree species. Human influence on the vegetation is not detectable during this time (LUP 1).

Abies and Fagus immigrated simultaneously at the end of the Atlantic period and increased rapidly. They lead to a decrease of the oak forest, Pinus and Corylus shortly after immigration. First Abies expanded more rapidly and dominated the early fir-beech forests. The later domi- nance of Fagus from the middle of the Subboreal period onwards is more the result of a decrease in the other pollen types (Fig. 3a, 4), maybe caused by a more stable population of Fagus in contrast to other tree species.

From the beginning of the Sub-Boreal period onwards, at $210 \mathrm{~cm}$ depth (Fig. 2), sedge peat and dwarf-shrub peat alternate. This points to alternating wetness levels in the bog. Sedge peat was a result of wetter phases, Ericaceae indicate a drier bog surface. Immigration of Carpinus betulus at the end of the Sub-Boreal period (Fig. 3a) was incomplete and the representation of Carpinus in the diagram is very low. The following vegetation history of the study area was strongly influenced by human impact.

\subsection{Human impact}

In the pollen diagrams (Figs. 3a and b), signs of influence from human activities can be detected in the vegetation record. Five different land use phases (LUP, Table 3, Figs. 3a and b) can be distinguished, with different levels of human impact characterised by pollen types indicative of agricultural and settlement activities (BEHRE 1981, 1988 and LANG 1994).

The land use phase 2 (LUP 2, 4000-2500 BC) covers the time from the Younger to the Late Neolithic period, at the transition from the Atlantic to the Subboreal period (approx. 3100 B.C.). The first phase of human impact is characterised by the increase of Poaceae and heliophilous herbs and the appearance of Plantago lanceolata, as well as the immediate decline of Abies. A high number of charcoal particles indicate local fires. Only charcoal pieces larger than $38 \mu \mathrm{m}$ have been counted, because these can be correlated with local fires (CLARK et al. 1989). Nevertheless, very extensive fires can transport larger charcoal particles for longer distances (TINnER et al. 2006). Natural fires are possible in coniferous forests, but here charcoal particles occur contemporaneously with secondary anthropogenic indicators (Fig. 3a, Table 3). Therefore this may be better explained by human settlement and woodland pasture in the valleys during the Younger Neolithic period. At the end of this land use phase, agriculture may have occurred, as a single grain of Hordeum type was ascertained. Barley (Hordeum vulgare) cultivation is known for the Younger 
Neolithic onwards (KörBER-Grohne 1995) and LUP 2 is representing the Late Neolithic. This should be a local evidence for agriculture, because the pollen from seeds do not fly long distances (BEHRE 1988). The following increase in Betula could be the result of a succession on the abandoned farmland. The land use phase 2 covers the time from the Younger to the Late Neolithic period, at the transition from the Atlantic to the Sub-Boreal periods (approx. 3100 B.C.).
The pollen diagram from the Maxe bog (FIrBAs et al. 1948) shows a similar decrease of Abies and an increase of Betula values, therefore supporting the notion of a regional land use pattern. This phase is contemporaneous to a known settlement in the Donon Range (see chapter 2). Human impact has been recognised in the Southern Black Forest at the same time (Steerenmoos, Human Impact Phase 4 of RöscH 2000). This leads to the conclusion that the climatic condi-

Tab. 3: Land use phases in the area of Rond Pertuis as differentiated in the pollen diagram (Fig. 3). Definition of primary and secondary anthropogenic indicators following BEHRE (1981, 1988) and LANG (1994).

Tab. 3: Aus dem Pollendiagramm (Abb. 3) hergeleitete Landnutzungsphasen für das Gebiet des Rond Pertuis. Primäre und sekundäre Indikatoren anthropogener Aktivität nach BEHRE (1981, 1988) und LANG (1994).

\begin{tabular}{|c|c|c|c|c|c|}
\hline \multirow{2}{*}{ LUP } & Depth in cm & \multirow{2}{*}{$\begin{array}{l}\text { Primary } \\
\text { anthropogenic } \\
\text { indicators }\end{array}$} & \multirow{2}{*}{$\begin{array}{l}\text { Secondary anthropogenic } \\
\text { indicators }\end{array}$} & \multirow{2}{*}{ Changes in forest composition } & Era \\
\hline & Age in $B C / A D$ & & & & Possible land use \\
\hline \multirow{2}{*}{$5 d$} & $8-0$ & \multirow{2}{*}{ Triticum } & \multirow{2}{*}{$\begin{array}{l}\text { Plantago lanceolata, } \\
\text { Brassicaceae and } \\
\text { Cichorioideae in low } \\
\text { quantities }\end{array}$} & \multirow{2}{*}{$\begin{array}{l}\text { Abundant Pinus and Picea; } \\
\text { decrease of Abies, Fagus and } \\
\text { Betula; more Castanea sativa }\end{array}$} & Youngest Modern Era \\
\hline & 1950 AD-today & & & & $\begin{array}{l}\text { Silviculture, grassland } \\
\text { farming }\end{array}$ \\
\hline \multirow[t]{2}{*}{$5 c$} & $24-8$ & \multirow[t]{2}{*}{$\begin{array}{l}\text { Several } \\
\text { Secale grains }\end{array}$} & \multirow{2}{*}{$\begin{array}{l}\text { Plantago lanceolata, } \\
\text { Artemisia and } \\
\text { Ranunculaceae continuous; } \\
\text { high Poaceae values; } \\
\text { sporadic Brassicaceae, } \\
\text { Urtica and Plantago media; } \\
\text { charcoal levels elevated }\end{array}$} & \multirow{2}{*}{$\begin{array}{l}\text { Abies decline; Pinus elevated; } \\
\text { Betula increase; earliest Picea } \\
\text { cultivation; Fagus, Quercus and } \\
\text { Corylus reduced }\end{array}$} & Modern Era \\
\hline & 1700-1950 AD & & & & $\begin{array}{l}\text { Silviculture, pasture } \\
\text { farming }\end{array}$ \\
\hline \multirow{2}{*}{$5 b$} & $52-24$ & \multirow{2}{*}{$\begin{array}{l}\text { At first some } \\
\text { Hordeum grains, } \\
\text { later Secale and } \\
\text { Triticum, as well as } \\
\text { Cannabis; a single } \\
\text { grain of Fagopyrum }\end{array}$} & \multirow{2}{*}{$\begin{array}{l}\text { Continuous high frequencies } \\
\text { of Plantago lanceolata; } \\
\text { Chenopodiaceae, } \\
\text { Brassicaceae and } \\
\text { Cichorioideae abundant; } \\
\text { Poaceae increase; charcoal } \\
\text { common }\end{array}$} & \multirow{2}{*}{$\begin{array}{l}\text { Pinus, Abies and Fagus decline; } \\
\text { Corylus and Betula spread; } \\
\text { Juglans from the beginning; } \\
\text { Castanea from the middle of } \\
\text { the phase onwards }\end{array}$} & $\begin{array}{l}\text { Central Medieval Ages to } \\
\text { early Modern Era }\end{array}$ \\
\hline & 1150-1700 AD & & & & $\begin{array}{l}\text { Charcoal burning, mining, } \\
\text { agriculture and pasture } \\
\text { farming }\end{array}$ \\
\hline \multirow{2}{*}{$5 a$} & $80-52$ & \multirow{2}{*}{$\begin{array}{l}\text { Several } \\
\text { Hordeum grains }\end{array}$} & \multirow{2}{*}{$\begin{array}{l}\text { Plantago lanceolata } \\
\text { reduced; Trifolium, } \\
\text { Chenopodiaceae and } \\
\text { Plantago in low quantities }\end{array}$} & \multirow{2}{*}{ Pinus increase } & $\begin{array}{l}\text { Roman Ages to } \\
\text { central Medieval Ages }\end{array}$ \\
\hline & $\begin{array}{l}400 \mathrm{BC}- \\
1150 \mathrm{AD}\end{array}$ & & & & $\begin{array}{l}\text { Pasture farming, limited } \\
\text { agriculture }\end{array}$ \\
\hline \multirow{2}{*}{4} & $132-80$ & \multirow{2}{*}{ None } & \multirow{2}{*}{$\begin{array}{l}\text { Plantago lanceolata } \\
\text { continuous; Artemisia } \\
\text { distinct; Chenopodiaceae, } \\
\text { Urtica and Plantago major } \\
\text { with low values; charcoal } \\
\text { elevated }\end{array}$} & \multirow{2}{*}{$\begin{array}{l}\text { Pinus elevated; } \\
\text { higher representation of Fagus } \\
\text { than Abies }\end{array}$} & $\begin{array}{l}\text { Middle Bonze Age to } \\
\text { younger Iron Age }\end{array}$ \\
\hline & $1800-400 \mathrm{BC}$ & & & & Pasture farming \\
\hline \multirow{2}{*}{$3 b$} & $160-132$ & \multirow{2}{*}{ None } & \multirow{2}{*}{$\begin{array}{l}\text { Plantago lanceolata, } \\
\text { Trifolium, Artemisia, } \\
\text { Chenopodiaceae, } \\
\text { Cichorioideae present; } \\
\text { Poaceae increase }\end{array}$} & \multirow{2}{*}{$\begin{array}{l}\text { Abies values increase towards } \\
\text { the middle of the period, than } \\
\text { decrease. Fagus becoming } \\
\text { dominant; at the end Pinus } \\
\text { frequencies rise }\end{array}$} & Early Bonze Age \\
\hline & 2200-1800 BC & & & & $\begin{array}{l}\text { Temporary } \\
\text { woodland pasture }\end{array}$ \\
\hline \multirow{2}{*}{ За } & $188-160$ & \multirow{2}{*}{ None } & \multirow{2}{*}{$\begin{array}{l}\text { Plantago major, presence } \\
\text { of Chenopodiaceae and } \\
\text { Ranunculaceae }\end{array}$} & \multirow{2}{*}{$\begin{array}{l}\text { At the beginning high levels of } \\
\text { Betula; Abies is spreading }\end{array}$} & Late Neolithic \\
\hline & 2500-2200 BC & & & & No land use detectable \\
\hline \multirow{2}{*}{2} & 224-188 & \multirow{2}{*}{$\begin{array}{l}\text { Hordeum grain } \\
\text { at the end of the } \\
\text { phase }\end{array}$} & \multirow{2}{*}{$\begin{array}{l}\text { Plantago lanceolata distinct; } \\
\text { Poaceae and charcoal } \\
\text { elevated; low values of } \\
\text { Artemisia, Ranunculaceae } \\
\text { and Plantago lanceolata }\end{array}$} & \multirow{2}{*}{$\begin{array}{l}\text { Abies and Fagus immigration } \\
\text { and spreading; Abies decline; } \\
\text { Betula percentages increase at } \\
\text { the end }\end{array}$} & Younger to late Neolithic \\
\hline & $4000-2500$ BC & & & & $\begin{array}{l}\text { Woodland pasture, first } \\
\text { agriculture }\end{array}$ \\
\hline & $240-224$ & & Artemisia, Ranunculaceae & & Younger Neolithic \\
\hline$\perp$ & $5000-4000$ BC & TVUTाE & quantities & 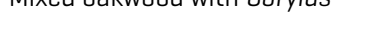 & No land use detectable \\
\hline
\end{tabular}


tions during this time must have permitted agriculture in the montane zone.

According to Firbas et al. (1948) the proportions of Fagus and Abies in the forest depend on the altitude. The dominance of Fagus increases with altitude. In the Northern Vosges (Maxe bog and Rond Pertuis supérieure area) the dominance of Fagus may have been caused by human impact as indicated in RPAZ 2 (Fig. 3a). A decline of the dominant forest tree Abies corresponds to an increase of secondary cultural indicators. Afterwards Fagus expands slowly. Hence the development of altitudinal vegetation zones, especially in the upper montane Fagus zone (6001000m) (Firbas et al. 1948), may have been triggered by human activity. This may also have led to the slow increase in Fagus values, as discussed by van der KNAAP et al. (2005) for sites in the Alps.

In the following period (LUP 3a, 2500-2200 B.C.) anthropogenic influences are not detectable in the Northern Vosges. The area was covered by an Abies and Fagus dominated forest (Fig. 3a, RPAZ 3). This period up until the Roman Ages is not represented in the analysis of the Maxe bog (Firbas et al. 1948), shown by the sharp lithostratigraphic change.

In the Early Bronze Age temporal land use is recognised by the slightly enhanced values of heliophilous herbs and Poaceae towards the end of this phase (LUP 3b, 22001800 B.C.). In the middle of the Sub-Boreal period Fagus becomes the dominant tree species with pollen frequencies higher than $25 \%$. The distinctive decline of the Abies values, while those of Fagus and Corylus increase, may indicate a selective cutting of fir trees by humans. Subsequently the Pinus values also increase while the curve of Abies does not show a rise to the same high level as before. Slightly elevated amounts of charcoal particles are also found, pointing to the occurrence of local forest fires, probably associated with the cutting of Abies trees. Abies was used as construction timber, a connection with the first mining activities is possible.

From the Middle Bronze Age and Younger Iron Age (LUP 4, 1800-400 B.C.) up to now, continuous human impact is detectable. Secondary cultural indicators indicate pasture and animal husbandry with forest grazing in the surrounding areas of the mire until the Younger Iron Age (Fig. 3a, b, Tab. 3). In the pollen diagram (Fig. 3a,b) Pinus, Alnus (alder), Salix (willow) and Calluna increase in LUP 4, which may be due to local drying of the bog surface leading to the local expansion of these species.

Thereafter Younger Iron Age farming is indicated by the occurrence of Hordeum type pollen grains (LUP 5a, 400 B.C.-A.D. 1150). During Roman times elevated levels of Calluna point to drier conditions or even a hiatus. Peat accumulation rates were very low and this time period is not well documented in the record.

The Vosgean valleys have been cleared and developed since the Middle Ages, as well as the 'chaumes' in the subalpine zone on the top of the mountains (GARNIER 2000). In the late Middle Ages and the early Modern Era, the forests around Rond Pertuis were partly cleared and severely altered by humans (LUP 5b, A.D. 1150-1900) as documented in Fig. 3a. The woodland was very likely intensively used for charcoal production. Near the investigated cirque sev- eral historical charcoal kilns were found. This is also the time when a forest edict of King Louis XIV in 1669 changed forest use in the Vosges from the cutting of individual trees to more intense forest exploitation (GARNIER 2000). A succession in the exploited forests is shown by the increase of Corylus and Betula (RPAZ 5).

The nearby settlements were related to iron-ore mining in the valley of the Breusch from the $13^{\text {th }}$ to the $19^{\text {th }}$ century (GEYER 1995). Agriculture is likely to have been very diverse during this period since a broad range of primary anthropogenic indicators, including Secale (rye), Triticum type (wheat) and Fagopyrum (buckwheat), were observed (Fig. 3b). A high number of Cannabis/Humulus type grains is recorded for the Late Middle Ages. During this time the textile industry developed, based on locally produced wool, hemp and flax, which was a common home industry in the Vosges (Michna 1977). This may be indicated in the pollen diagram. During the $19^{\text {th }}$ century, agriculture decreased and textile manufacturing was the driving force of settlement development in the Vosges (Stadelbauer 1992). The textile industry changed during this time through mechanization and the raw material now most commonly used was cotton (Michna 1977). This change may have led to the collapse of hemp farming.

The spreading of Quercus during the Late Middle Ages may be a result of its use for coppicing practice and the use of oak bark in tanneries, and may furthermore be attributed to the general use of oak stands during the Medieval Ages and the early Modern Era for pig fodder (acorns). Mining was intense during this time (GRANIER 2000) leading to a distinct decrease of Abies. The interrupted mining activities in the $17^{\text {th }}$ century could have led to a recovery of the Abies population (FrIEDMANN 2000, MäCKEL et al. 2009). However also in the Modern Era the woodlands were afforested by Abies and Pinus. Most recently Abies declined due to the introduction of Picea. The appearance of Picea abies in the Central Vosges may date to 50 B.C.-A.D. 80 (KALIs et al. 2006). Afterwards Picea may have grown in isolated localities, e.g. deep cool canyons, in the central Vosges (KALIs 1984). As a result of the degradation of the forest by overexploitation during the $17^{\text {th }}$ and $18^{\text {th }}$ centuries (DION 1970), it is likely that spruce spread from the isolated stands. The plantation of Picea forests began in the 1850s (CLOSSETKopp et al. 2006). The decreasing population density after the First World War (FrEY 1964) may also have helped the spreading of Picea (Dion 1970).

For the study area in the Northern Vosges, FirBAs et al. (1948) describe a fir forest around the Maxe bog. The younger radiocarbon date for the sample at the depth of $18-21 \mathrm{~cm}$ (Table 1 ), representing the time of spruce spreading, may be the result of dating a bulk sample containing rootlets. Today's forest is a spruce monoculture; Abies and Fagus are only growing in higher areas of the Northern Vosges Mountains from $700 \mathrm{~m}$ a.s.l. upwards, but not within the cirques.

Land use phase 5c (A.D. 1900-recent time) is characterised by silviculture and pasture farming. The detected $S e-$ cale pollen (Fig. 3b) may originate from rye fields at greater distances, because of its high pollen production and excellent dispersal capacity (Burga \& PERrET 1998). The increasing number of charcoal particles could be a possible 
sign of slash-and-burn agriculture, which was practised for a long time in the Northern Vosges (Herrmann 1914).

Apart from silviculture, grassland farming characterizes the youngest Modern Era (LUP 5d, A.D. 1950-today). Also Cerealia pollen are detected in higher numbers. Additionally, wheat, potato and cattle fodder are cultivated in the Breusch Valley (Timbal 1985, Sick 1991). In most recent times the forests suffered from strong storms (named e.g. Vivian and Wiebke in 1990, and Lothar in 1999), and large forest areas have been blown over. Future succession and modern silviculture will likely lead to more diverse and species-rich forests.

\subsection{Regional Context}

The vegetation history of the Northern Vosges shows certain similarities to the development in the Southern Vosges (Janssen et al. 1972, 1975, de VAlK 1981, Edelman 1985, KALIS 1985), but also distinct differences (FrIEDMANN 2000). During the Preboreal a pine-birch forest covered the whole Vosges Mountains. Then regional differences in the vegetation development become apparent. In the Boreal the immigration of hazel, elm, oak and other thermophilous trees occur. The hazel expansion in the Southern Vosges was very strong, but much reduced in the Northern Vosges (FIRBAs et al. 1948, BunNiK 1978). The hazel-rich oak forests largely replace during the Atlantic the pine-birch forests in the Southern Vosges, but in the Northern Vosges pine and to a lesser extent birch still constitute an important part of the forests. Beech and fir spread in the Southern Vosges from the middle Atlantic times onward and reach the Northern Vosges in the late Atlantic (Fig. 3a). In the Subboreal period the expansion of beech and fir lead to a decline of the mixed oakwood and also to a reduction of the pine in the Northern Vosges. The long dominance of pine might be a result of the permeable sandstone rock and more acid soil conditions in the Northern Vosges, which gave pine an ecological advantage over other trees. During the Subatlantic the forests are severely changed by human impact in the whole Vosges Mountains. Spruce was able to establish itself in a few areas of the Southern Vosges with particularly harsh climatic conditions (KALIs et al. 2006), but not in the Northern Vosges. The modern forest cover rich in spruce is a result of plantations.

The main differences of the vegetation history of the Vosges to the Black Forest concern the role of the spruce (Friedmann 2000, Rösch 2000). The spruce naturally immigrated and spread slowly into the Black Forest from the east during the early Atlantic. Mass expansion of the spruce into the high, middle and northern Black Forest occured during the Subatlantic.

\section{Conclusion}

The presented pollen diagram fills an important gap in knowledge of the Holocene vegetation development and land use history of the Northern Vosges and the Central European Uplands. There is a high persistency of Pinus in the Northern Vosges until the middle Holocene period. These high frequencies of Pinus in the northern sandstone Vosges are probably a natural phenomenon, resulting from the special local site conditions (more acidic soils on the permeable sandstone bedrock) and the relatively late immigration and spread of Abies and Fagus. This immigration led to a decrease of Pinus. Abies spread earlier than Fagus, but soon diminished, most likely because of early human use. Human activity has certainly influenced the development of the high-montane Fagus zone in this area, probably driven by the selective use of Abies. Human impact on the vegetation of the Northern Vosges started in the late Atlantic period and increased until the Late Medieval Ages. Land use in association with mining led to cutting of the forest at the Rond Pertuis supérieure in the early Modern Age. Also the changing raw materials used by the textile industry in the Vosges may be recognized in the vegetation development. Picea pollen is detected during the time of silviculture for the first time and therefore a natural immigration in the Northern Vosges is undiscernible.

\section{Acknowledgements}

Part of this work was supported by the Deutsche Forschungsgemeinschaft (DFG) and originates from the interdisciplinary research college "Formation and Development of Present Day Landscapes" (Graduiertenkolleg "Gegenwartsbezogene Landschaftsgenese", GRK 962) at the Department of Physical Geography, Albert-Ludwigs-University Freiburg. Laboratory work was done at the Palynological Laboratory of the Institut für Vor- und Frühgeschichte und Provinzialrömische Archäologie of the LMU München. Radiocarbon dating was realised by the Heidelberger Akademie der Wissenschaften. Finally we thank F. Bunnik, J.-N. Haas, R. Jahnsen, H. Küster, S. Wolters for helpful comments and H. Sudhaus for GIS support.

\section{References}

BEHRE, K.-E. (1981): The interpretation of anthropogenic indicators in pollen diagrams. - Pollen et Spores, 23: 225-245.

Behre, K.-E. (1988): The role of man in European vegetation history. In: Huntley, B. \& WebB, T. (eds.): Vegetation history: 633-672; Dortrecht (Kluwer Academic publ).

BennetT, K. D. (2009): psimpoll and pscomb programs for plotting and analysis. - http://chrono.qub.ac.uk/psimpoll/psimpoll.html.

Beug, H. J. (2004): Leitfaden der Pollenbestimmung für Mitteleuropa und angrenzende Gebiete. - 542 S.; München (Pfeil).

BREUNING, T. (1998): Überarbeitung der naturräumlichen Gliederung Baden-Württembergs auf Ebene der naturräumlichen Haupteinheiten. - Naturschutz Info, H. 1/98: 55-58.

BunNik, F. P. M. (1978): Een pollenanalytisch verslag van twee venen uit de noordelijke Vogezen (Champ du Feu, Col de Prayê). - Diploma Thesis, University of Utrecht, Netherlands.

Burga, C. $\mho$ Perret, R. (1998): Vegetation und Klima der Schweiz seit dem jüngeren Eiszeitalter. - 805 S.; Thun (Ott Verlag).

Clark, J. S., Merkt, J. \& Müller, H. (1989): Post-Glacial Fire, Vegetation, and Human History on the Northern Alpine Forelands, South-western Germany. - Journal of Ecology, 77: 897-925.

Closset-Kopp, D., Schnitzler, A. \& Aran, D. (2006): Dynamics in natural mixed-beech forest of the Upper Vosges. - Biodiversity and Conservation, 15: 1063-1093

Czarnowsky, G. (1947): Le Donon. Les fouilles de 1934-1938. - Cahiers d'archéologie et d'histoire d'Alsace, 38: 53-66.

DE VALK, E. J. (1981): Late holocene and present vegetation of the Kastelberg (Vosges, France). - Dissertation, University of Utrecht, Netherlands: 1-293.

Dion, J. (1970): Les Forêts de la France du Nord-Est. - Revue géographique de l'Est, 12 (i.e. 10): 155-277.

EdELman, H.J. (1985): Late glacial and Holocene vegetation development 
of la Goutte Loiselot (Vosges, France). - Dissertation, University of Utrecht, Netherlands: 1-196.

FÆgri, K. \& IVERSEn, J. (1989): Textbook of Pollen Analysis. - 328 S.; Chicheseter (Wiley).

Firbas, F., Grünig, G., Weischedel, I. ¿ Worzel, G. (1948): Beiträge zur spät- und nacheiszeitlichen Vegetationsgeschichte der Vogesen. Bibliotheca Botanica, 121: 1-76.

Frey, C. (1964): Vergleichende Betrachtung zur Kulturgeographie von Vogesen und Schwarzwald. - Regio Basiliensis, 5: 44-62.

Frey, C. (1965): Morphometrische Untersuchung der Vogesen. - Basler Beiträge zur Geographie und Ethnologie, Geographische Reihe, 6: $1-150$.

FriedmanN, A. (2000): Die spät- und postglaziale Landschafts- und Vegetationsgeschichte des südlichen Oberrheintieflands und Schwarzwalds. - Freiburger Geographische Hefte, 62: 1-222.

Garnier, E. (2000): 'The Coveted Tree': the Industrial Threat to the Vosges Forest in the $16^{\text {th }}$ and $18^{\text {th }}$ Centuries. - In: AgNoletti, M. \& ANDERson, S. (eds.): Forest History: International Studies on Socio-economic and Forest Ecosystem Change; Report No. 2 of the IUFRO Task Force on Environmental Change: 37-47; Wallingford (CABI Pub.).

GevelaAr, A. J. (1982): Palynologie van de Marais de la Max, noordelijke Vogezen. - Diploma thesis, University of Utrecht, Netherlands.

GEYER, M. (1995): Historische Bergbaureviere in den Vogesen. - Jahresberichte und Mitteilungen des Oberrheinischen Geologische Vereins, N.F. 77: $247-264$

GRIMM, E. C. (1987): CONISS: a fortran-77 program for stratigraphically constrained cluster analysis by the method of incremental sum of squares. - Computers \& Geosciences, 13: 13-35.

HATT, J. P. (1937): Contribution à $l$ 'analyse pollinique des tourbières du nord-est de la France. - Bulletin du service de la carte géologique d'Alsace et de Lorraine, 4: 1-79.

Herrmann, A. (1914): Die Allmenden im Bezirk Unter-Elsaß: eine sozialwirtschaftliche Studie. - 155 S., Straßburg (Strassburger Druck und Verlags-Anstalt).

Huntley, B. \& WebB, T. (1988) (eds.): Vegetation History. - 803 S., Dordrecht (Kluwer Academic Publishers).

Janssen, C.R. \& Janssen-Kettuitz, E.L. (1972): A post-Atlantic pollen sequence from the tourbière du Tanet (Vosges, France). - Pollen et Spores, 14: 65-76.

Janssen, C.R., Cup-Uiterwijk, M.J.J., Edelman, H.J., Mekel-Te Riele, J \& PALS, J.P. (1975): Ecologic and palaeoecologic studies in the Faigne d'Artimont (Vosges, France). - Vegetatio, 30 (3): 165-178.

Jarvis, A., Reuter, H. I., Nelson, A. \& Guevara, E. (2008): Hole-filled seamless SRTM data V4. - International Centre for Tropical Agriculture (CIAT), available from http://srtm.csi.cgiar.org

Kalis, A. J. (1984): L'Indigenat de l'Epicea dans les hautes Vosges. - Revue de Paléobiologie, Vol. Spécial, 1: 103-115.

KALIS, A.J. (1985): Foret de la Bresse (Vogezen). Vegetatiekundige en pollenanalytische onderzoekingen naar de bosgeschiedenis van een Centraal-Europees middelgebergte. - Dissertation, University of Utrecht, Netherlands: $1-349$

Kalis, A. J., van der KnaAp, W. O., Schweizer, A. \& Urz, R. (2006): A three thousand year succession of plant communities on a valley bottom in the Vosges Mountains, NE France, reconstructed from fossi pollen, plant macrofossils, and modern phytosociological communities. - Vegetation History and Archaeobotany, 15: 377-390.

KörBer-Grohne, U. (1995): Nutzpflanzen in Deutschland von der Vorgeschichte bis heute. - 490 S.; Hamburg (Nikol).

LANG, G. (1994): Quartäre Vegetationsgeschichte Europas, Methoden und Ergebnisse. - 462 S.; Jena, Stuttgart (Fischer).

LASSERE, M. (2007): Les nécropoles tumulaires de la forêt de la Hardt: un rééquiliberage de l'occupation funéraire sur l'ensamble du territoire. - Bilan scientifique: Alsace, 2007/1: 191-197.

LiNCKENHELD, E. (1947): Le sanctuaire du Donon, son Importance pour l'Ėtude des Cultes et des Rites celtiques d'après les recentes découvertes. - Cahiers d'archéologie et d'histoire d'Alsace, 38: 67-110.
Mäckel, R., Friedmann, A. ひ Sudhaus, D. (2009): Environmental changes and human impact on landscape development in the upper Rhine region. - Erdkunde 63/1: 35-49.

MichNA, R. (1977): Wandlungen in der Textilindustrie der Südvogesen unter besonderer Berücksichtigung des oberen Dollar- und Savoureusetales. - Thesis, University of Freiburg, Germany.

Moore, P. D., WebB, J. A. \& Collinson, M. E. (1991): Pollen Analysis. 216 S.; Oxford (Blackwell Scientific).

MüLlER, F. T. (1905): Die Erzlagerstätten von Rothau und Framont im Breuschtal (Vogesen). - Thesis, University of Strasbourg, France.

ReILLE, M. (1992): Pollen et spores d'Europe et d'Afrique du Nord. - 529 S.; Marseille (Laboratoire de Botanique Historique et Palynologie)

Reimer, P. J., BAillie, M. G. L., BARD, E. et al. (2009): IntCal09 and Marine09 radiocarbon age calibration curves, 0-50,000 years cal BP. Radiocarbon, 51: 1111-1150.

REKLIP (Trinationale Arbeitsgemeinschaft Regio-Klima-Projekt) (1995): Klimaatlas Oberrhein Mitte-Süd. - Offenbach (IFG).

Rösch, M. (2000): Long-term human impact as registered in an upland pollen profile from the southern Black Forest, south-western Germany. - Vegetation History and Archaeobotany, 9: 205-218.

Sell, Y., Bercholdt, J. P., Callot, H., Hoff, M., Gall, J. C. \& Walter, J. M. (1998): L'Alsace et les Vosges. Géologie, milieux naturels, flore et faune. - 352 S.; Lausanne (Delachaux et Niestlé).

Sick, W.-D. (1991): Die Agrarwirtschaft im Elsaß - mit Vergleichen zu Südbaden. - Alemannisches Jahrbuch, 1987/88: 287-310.

Sponagel, H. (ed.) (2005): Bodenkundliche Kartieranleitung. - 438 S., Stuttgart (Schweizerbart)

StADELBAUER, J. (1992): Ressourcenbewertung und Siedlungsentwicklung in höheren Mittelgebirgen am Beispiel der Vogesen. - Siedlungsforschung, 10: 79-104.

STOCKMARR, J. (1971): Tablets with spores used in absolute pollen analysis. - Pollen et Spores, 13: 615-621.

SudHAus, D. (2005): Paläoökologische Untersuchungen zur spätglazialen und holozänen Landschaftsgenese des Ostschwarzwaldes im Vergleich mit den Buntsandsteinvogesen. - Freiburger Geographische Hefte, 64: 1-153.

SugITA, S. (1993): A model of pollen source area for an entire lake surface. - Quarternary Research, 39: 239-244.

SugrtA, S. (1994): Pollen representation of vegetation in Quaternary sediments: Theory and method in patchy vegetation. - Journal of Ecology, 82: 881-897.

Theuerkauf, M., Bos, J.A.A., Jahns, S., Janke, W., Kuparinen, A. Stebich, M. \& Joosten, H. (2014): Corylus expansion and persistent openness in the early Holocene vegetation of northern central Europe. - Quaternary Science Reviews, 90: 183-198.

Timbal, J. (1985): Carte de la végétation de la France, sheet Alsace, No.28, 1:200 000. - Paris (IGN).

Tinner, W., Hofstetter, S., Zeugin, F., Conedera, M., Wohlgemuth, T., ZimmermanN, L. \& Zweifel, R. (2006): Long-distance transport of macroscopic charcoal by an intensive crown fire in the Swiss Alps - implications for fire history reconstruction. - The Holocene, 16: 287-292.

van der Knaap, W. O., van Leeuwen, J. F. N., Finsinger, W., Gobet, E., Pini, R., Schweizer, A., Valsecchi, V. \& Ammann, B. (2005): Migration and population expansion of Abies, Fagus, Picea, and Quercus since 15000 years in and across the Alps, based on pollen-percentage threshold values. - Ouaternary Science Reviews, 24: 645-680.

Walter-Simonnet, A.-V., Bossuet, G., Develle, A.-L., BÉgeot, C., RufFALDI, P. et al. (2008): Chronologie et spatialisation de retombées de cendres volcaniques tardiglaciaires dans les massifs des vosges et du jura, et le plateau suisse. - Quaternaire, 19: 117-132.

ZWANDER, H. (1997): Untersuchungen zum Pollenflug in der freien Landschaft. - Carinthia II, 187: 423-445. 